\title{
Review
}

\section{Rho GTPase signalling pathways in the morphological changes associated with apoptosis}

\author{
ML Coleman ${ }^{1}$ and MF Olson ${ }^{\star, 1}$ \\ ${ }^{1}$ Cancer Research Campaign Centre for Cell and Molecular Biology, Institute of \\ Cancer Research, 237 Fulham Road, London SW3 6JB, UK \\ * Corresponding author: MF Olson, Abramson Family Cancer Research \\ Institute, Room 411, BRB II/III, 421 Curie Boulevard, University of \\ Pennsylvania, Philadelphia, PA 19104-6160, USA. Tel: +1 2157466798 \\ Fax: +1 215746 5525; E-mail: molson@mail.med.upenn.edu
}

Received 23.8.01; revised 26.10.01; accepted 5.11.01

Edited by M Piacentini

\begin{abstract}
The killing and removal of superfluous cells is an important step during embryonic development, tissue homeostasis, wound repair and the resolution of inflammation. A specific sequence of biochemical events leads to a form of cell death termed apoptosis, and ultimately to the disassembly of the dead cell for phagocytosis. Dynamic rearrangements of the actin cytoskeleton are central to the morphological changes observed both in apoptosis and phagocytosis. Recent research has highlighted the importance of Rho GTPase signalling pathways to these changes in cellular architecture. In this review, we will discuss how these signal transduction pathways affect the structure of the actin cytoskeleton and allow for the efficient clearance of apoptotic cells.

Cell Death and Differentiation (2002) 9, 493-504. DOI: 10.1038/ sj/cdd/4400987
\end{abstract}

Keywords: Rho; Rac; ROCK; actin cytoskeleton; myosin light chain; phagocytosis; blebbing

Abbreviations: GDI, GDP-Dissociation Inhibitor; GEF, guanine nucleotide exchange factor; GAP, GTPase accelerating protein; MLC, myosin light chain

\section{Introduction}

Apoptosis is an evolutionarily conserved process in multicellular organisms that leads to the death and subsequent removal of redundant or excess cells. In the dying cell, a family of cysteine-proteases called caspases (reviewed in reference ${ }^{1}$ ) are responsible for the 'execution' phase which is characterised by morphological changes, including cell contraction and dynamic membrane blebbing (Figure 1), one of the earliest described and most obvious aspects of apoptotic cell death. ${ }^{2}$ Contractile force generated by actinmyosin II cytoskeletal structures has been implicated as the driving power behind cell contraction and the formation of membrane blebs and apoptotic bodies (reviewed in reference ${ }^{3}$ ). Ultimately, the dead cell is packaged into membraneclad apoptotic bodies that facilitate uptake by neighbouring cells or by specialised phagocytic cells. Dynamic rearrangements of the actin cytoskeleton in the phagocyte are required for the internalisation of apoptotic cell fragments. Recent research has revealed the importance of signal transduction pathways controlled by Rho family GTPases in regulating the marked changes in cell morphology observed in the processes of apoptosis and phagocytosis.

The Rho GTPases are a family of proteins (RhoA, RhoB, RhoC, RhoD, RhoE/Rnd3, RhoG, RhoH/TTF, Rnd1, Rnd2, Rac1, Rac2, Rac3, Cdc42/G25K, Wrch-1, TC10, TCL, Chp, Rif) that act as molecular switches in intracellular signal transduction pathways (reviewed in reference ${ }^{4}$ ). Rho activation results from a combination of reduced association with GDP-Dissociation Inhibitors (GDIs) and enhanced exchange of GDP for GTP promoted by Guanine nucleotide Exchange Factors (GEFs). Activated GTP-bound Rho proteins then transduce signals to downstream effector proteins and finally, through association with GTPase Accelerating Proteins (GAPs), return to the inactive GDP-bound form by hydrolysis of the bound GTP (Figure 2). One of the key functions of Rho proteins is to regulate the architecture of the actin cytoskeleton (reviewed in reference ${ }^{5}$ ). The best characterised proteins of this family are RhoA, which leads to the formation of actin stress fibres and actin-myosin II contractile force generation, ${ }^{6,7}$ Rac1, which promotes the formation of lamellipodia and membrane ruffles ${ }^{8}$ and Cdc42/ G25K, which drives the formation of actin-rich filopodia. ${ }^{9,10}$

One theory that attempted to explain the cell contraction, membrane blebbing and apoptotic body formation observed in apoptotic cells was that caspase-mediated proteolysis of structural and cell adhesion proteins (Table 1) leads to a release from points of cell attachment followed by collapse of the cell. However, numerous lines of evidence have demonstrated that the first phase of cell contraction and membrane blebbing (Figure 1) is a dynamic process associated with, and dependent upon, the presence of filamentous actin, ${ }^{11-23}$ increased myosin light chain (MLC) phosphorylation $^{15,16,19,22,24}$ and myosin ATPase activity. ${ }^{15,16}$ After the initial phase of contraction and blebbing, a second phase of actin filament disassembly occurs via depolymerisation ${ }^{18,20}$ and possibly through caspasemediated cleavage of actin monomers. ${ }^{25-27}$

\section{First phase: contraction and blebbing}

Given the well-characterised effects of RhoA on promoting actin filament bundling and actin-myosin II contractile force generation, it was proposed that the activation of RhoA is responsible for the contraction observed in apoptotic cells. ${ }^{3}$ Consistent with this proposal, introduction of a constitutively- 


\section{Morphology Actin Cytoskeleton}
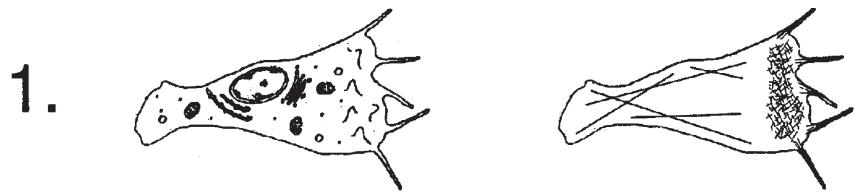

Adherent and well spread. Actin

stress fibres (Rho), membrane ruffles (Rac), microspikes (Cdc42).
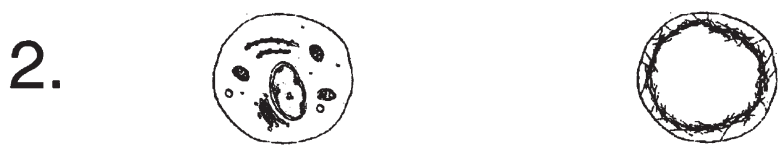

Loss of adhesion, cell rounding and contraction. Reorganisation of actin into cortical ring.
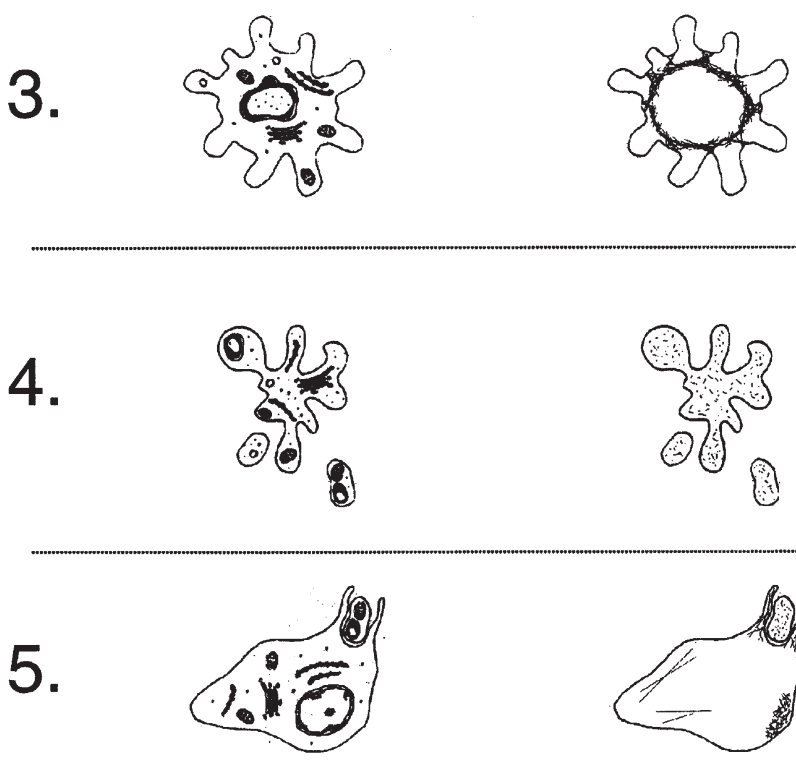

\section{Cellular organelles packaged into apoptotic bodies. \\ Actin cytoskeleton dismantled.}

Condensation of cytoplasm and chromatin. Contractile force generated by actin-myosin ring. Extrusion of blebs at points of weakness between actin and plasma membrane.

5 Engulfment of apoptotic bodies by phagocyte

active form of RhoA was shown to be sufficient for cell contraction and membrane blebbing. ${ }^{28,29}$

Resent research, however, has shown that activation of RhoA is unlikely to be a general mechanism responsible for apoptotic contraction and blebbing. RhoA was not activated in response to a pro-apoptotic stimulus in NIH 3T3 or Swiss 3T3 cells (EA Sahai and MF Olson, unpublished observation and reference ${ }^{23}$ ). In addition, inhibition of Rho with $C$. botulinum C3 toxin did not inhibit membrane blebbing ${ }^{23,24}$ or MLC phosphorylation. ${ }^{24}$ Signalling downstream of Rho, however, was essential, as pharmacological inhibition of the Rho effector kinase ROCK prevented membrane blebbing in a range of cell types, ${ }^{23,24}$ which was accompanied by diminished MLC phosphorylation. ${ }^{24}$ Active
ROCK I was shown to be sufficient for cell contraction and membrane blebbing in NIH 3T3 mouse fibroblasts, NIE-115 human neuroblastoma and Jurkat human $\mathrm{T}$ cells. ${ }^{23,24,30}$ Taken together, these data are consistent with increased actin-myosin II contractile force being driven by Rhoindependent ROCK activity that results in membrane blebbing during apoptosis.

In collaboration with other Rho effector proteins, ROCK contributes to agonist-induced changes to the actin cytoskeleton without necessarily producing dramatic contraction and blebbing. $^{31,32}$ The ROCK I and ROCK II isoforms bind to Rho-GTP, which activates the ROCK catalytic domain by displacing the carboxy-terminal autoinhibitory domain (Figure 3). ${ }^{33-35}$ Deletion of the inhibitory region increases kinase 
activity both in vitro and in vivo. ${ }^{34,36-38}$ During apoptosis, ROCK I, but not ROCK II, is cleaved by caspase-3 at a conserved sequence that removes the autoinhibitory do-

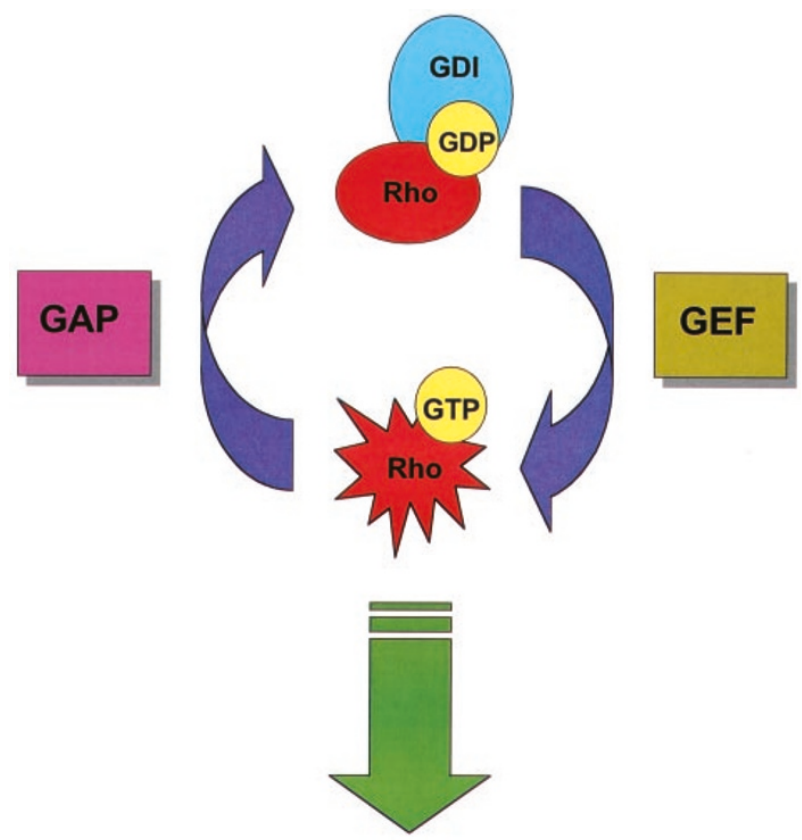

\section{Effectors}

Figure 2 Regulation of Rho GTPase cycle. Cycling of Rho GTPase between inactive GDP-bound and active-GTP bound states. GDI, GDP-Dissociation Inhibitor; GEF, Guanine nucleotide Exchange Factor; GAP, GTPase Accelerating Protein main. ${ }^{23,24}$ The truncated kinase has an eightfold higher specific activity in vitro relative to full-length protein in the absence of Rho. ${ }^{23}$ The enhanced kinase activity is sufficient to drive caspase-independent cell contraction and membrane blebbing (Figure 3), ${ }^{23,24}$ consistent with a direct effect of ROCK on the development of the apoptotic morphology.

ROCK activation positively contributes to actin-myosin force generation through the phosphorylation of a number of downstream target proteins (Figure 3). ROCK-dependent activation of LIM kinases-1 and $-2^{39-42}$ results in phosphorylation and inactivation of the actin-severing protein cofilin, thereby stabilising filamentous actin. ROCK also directly phosphorylates MLC, ${ }^{4-45}$ and phosphorylates and consequently inhibits MLC phosphatase. ${ }^{46,47}$ ROCK phosphorylation of calponin ${ }^{48}$ and $\mathrm{CPI}-17^{49}$ relieves their inhibition of myosin ATPase activity thereby promoting increased actin-myosin contractile force. Taken together, ROCK activation leads to a concerted series of events that promotes actin filament stabilisation, increased interaction with myosin and contractile force generation, which together drive cell contraction.

Membrane blebbing occurs where the strength of interactions that tether the plasma membrane to cytoskeletal structures is exceeded by the hydrodynamic force within the cell. ${ }^{50,51}$ Application of negative pressure to the exterior of cells allows bleb protrusion powered by the positive interior pressure, ${ }^{52}$ indicating that a pressure gradient between inside and outside of a cell is sufficient for blebbing. Alternatively, a reduction in the strength of interaction between the plasma membrane and the cytoskeleton may promote membrane blebbing, for example melanoma cells deficient in filamin, which links actin filaments to plasma membrane-associated proteins, bleb continuously. ${ }^{53}$ During apoptosis, caspase-mediated proteolysis of structural and

Table 1 Cytoskeletal, structural and regulatory proteins cleaved by caspases during apoptosis

\begin{tabular}{|c|c|c|c|}
\hline Protein & Function & Caspase & References \\
\hline Actin & Polymerised into filaments & 3 & 26 \\
\hline Gelsolin & Actin-severing & 3 & 140 \\
\hline Gas 2 & Actin filament binding & 3,7 & 141 \\
\hline Fodrin & Actin filament binding & 3 & 142,143 \\
\hline Beta II Spectrin & Actin filament binding & 3 & 144 \\
\hline Filamin & Actin filament binding & $?$ & 145 \\
\hline$\alpha$-adducin & Actin capping & 3 & 146 \\
\hline FAK & Regulates cell adhesion & 3,6 & 147,148 \\
\hline p130 Cas & Regulates cell adhesion & 3 & 149 \\
\hline Plectin & Microfilament cross-linker & 8 & 150 \\
\hline E-Cadherin & Cell-Cell adhesion & 3 & 151,152 \\
\hline N-Cadherin & Cell-Cell adhesion & 3 & 153 \\
\hline P-Cadherin & Cell-Cell adhesion & $?$ & 151 \\
\hline$\beta$-catenin & Cell-Cell adhesion & 3 & 154 \\
\hline$\gamma$-catenin & Cell-Cell adhesion & 3 & 155 \\
\hline Keratin-14 & Intermediate Filament & $?$ & 156 \\
\hline Keratin-15 & Intermediate Filament & $?$ & 157 \\
\hline Keratin-17 & Intermediate Filament & $?$ & 157 \\
\hline Keratin-18 & Intermediate Filament & $3,6,7$ & 158 \\
\hline Keratin-19 & Intermediate Filament & $?$ & 159 \\
\hline Vimentin & Intermediate Filament & 3 & 143,160 \\
\hline Tau & $\begin{array}{l}\text { Neuronal microtubule- } \\
\text { associated protein }\end{array}$ & 3 & 161,162 \\
\hline
\end{tabular}



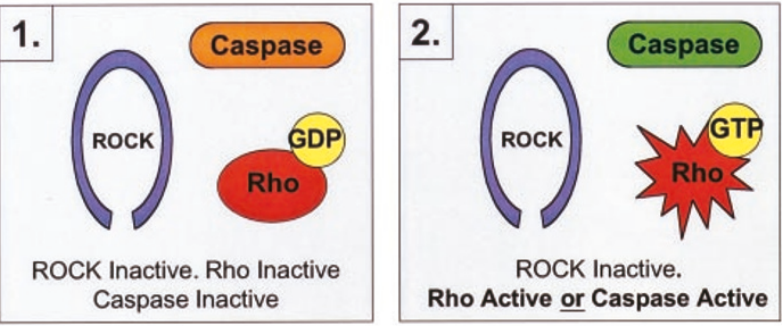

\section{ROCK Activated.}

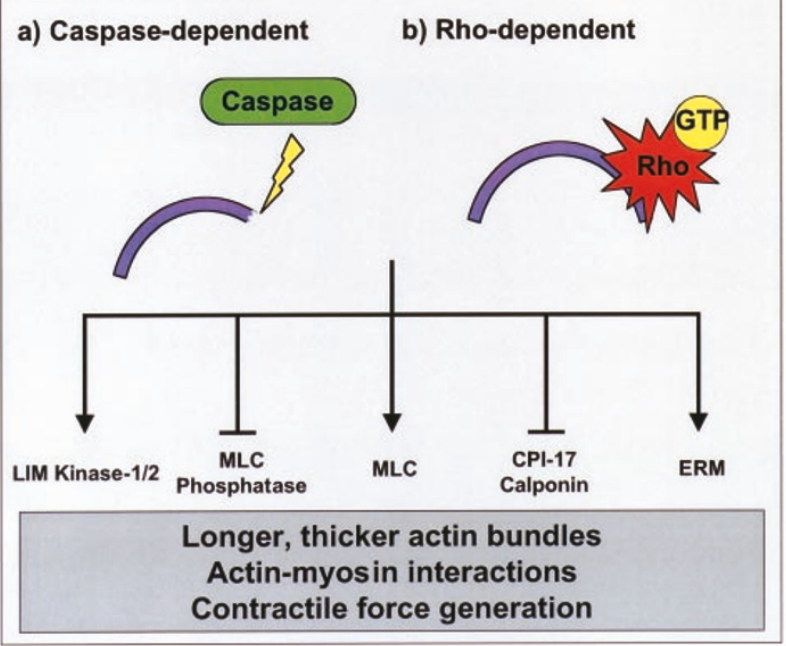

Figure 3 ROCK activation and phosphorylation of downstream targets. Loss of autoinhibition by Rho binding, or caspase cleavage results in kinase activation. ROCK phosphorylates a number of substrates that regulate actinmyosin-II contractile force generation. MLC, Myosin Light Chain

regulatory proteins (Table 1) diminishes the interactions that tethers the plasma membrane to the cytoskeleton and allows the increased hydrodynamic forces generated by ROCKinduced cell contraction to drive bleb protrusion at points of weakness (Figure 1). Although required for apoptotic body formation, ${ }^{11,23}$ blebbing can be sustained for prolonged periods of time and will not directly lead to a breakdown of the cell. ${ }^{15,23,24,27,30}$ Therefore, additional events are required for the blebbing cell to be broken down into apoptotic bodies.

\section{Second phase: breakdown of actin structures and apoptotic body formation}

After the initial phase of cell contraction and membrane blebbing driven by ROCK-mediated actin-myosin contractile force generation, there is a second phase in which actin filaments are depolymerised. ${ }^{18,20}$ Signalling downstream of Rho GTPases may contribute to both phases of actin reorganisation. During apoptosis, caspase-mediated cleavage of the Rho effector kinases PRK1 (also known as $\mathrm{PKN})^{54}$ and $\mathrm{PRK} 2^{55}$ as well as the Rac/Cdc42 effector kinase PAK2 (also known as $\gamma$-PAK) ${ }^{56,57}$ releases constitutively active kinase fragments. Catalytically active PRK1/PKN has been reported to promote actin stress fibre disassembly, ${ }^{58}$ possibly resulting from the phosphorylation of the actin binding protein $\alpha$-actinin as well as the phosphorylation of monomeric actin. ${ }^{59} \mathrm{~A}$ C-terminal fragment of PRK2 released by caspase-mediated proteolysis may feed forward to promote apoptosis by inhibiting the catalytic activity of the anti-apoptotic protein kinase Akt/PKB and reduce its inhibitory phosphorylation of the pro-apoptotic Bcl-2 family member Bad. ${ }^{60}$ PAK isoforms also have been shown to lead to actin stress fibre disassembly, ${ }^{23,61-63}$ possibly through the phosphorylation of the myosin-II heavy chain, ${ }^{64}$ which is thought to promote actin-myosin destabilisation, ${ }^{65}$ and through the phosphorylation and consequent inhibition of the MLC kinase. ${ }^{66,67}$ Overexpression of a dominant-negative form of PAK2 blocked Fas-induced apoptotic body formation in Jurkat T cells suggesting that PAK-mediated effects on actin filament depolymerisation and dismantling of cytoskeleton structures may be required for the final breakdown of the apoptotic cell. ${ }^{56}$ Interestingly, PAK1 and PAK2 isoforms have been shown to protect cells from apoptosis through the phosphorylation of the pro-apoptotic Bad protein. ${ }^{68-70}$ Thus, in some situations the activation of PAK2 by caspase-cleavage may antagonise both the morphological and biochemical events in a cell not fully committed to apoptosis.

\section{Caspase-cleaved Rho GTPase signalling proteins}

In addition to the proteins listed above, four additional proteins involved in Rho GTPase signalling have been identified as being caspase-cleaved in apoptotic cells. Given the importance of the Rho GTPase family in the regulation of the actin cytoskeleton, any significant changes to their signalling activities would likely influence the apoptotic morphology.

CDC42/Rac1 The Rho family GTPases Cdc42 and Rac1 were shown to be cleaved by caspases- 3 and -7 in a variety of cell lines during Fas-induced apoptosis. ${ }^{71}$ The cleavage occurs at a position that separates the $\mathrm{N}$-terminal portion of the protein containing the principal effectorinteraction domain from the C-terminal portion responsible for the essential localisation of the protein to membranous structures. Therefore, the most likely outcome of Cdc42 and Rac1 cleavage is the termination of downstream signalling. It has been suggested previously that Cdc42 and Rac1 signalling promote cell survival through the PAKmediated phosphorylation of $\mathrm{Bad}^{68-70}$ and through the activation of $\mathrm{NF}-\kappa \mathrm{B} .{ }^{72}$ Therefore, the cleavage of $\mathrm{Cdc} 42$ and Rac1 may further the apoptotic process by eliminating their normal function as pro-survival signalling proteins. In addition, by eliminating the actin filament destabilising actions of Cdc42 and Rac1 $1^{61,63,64}$ the effects of ROCK I on promoting actin-myosin II cell contractility would be accentuated.

D4-GDI In haematopoietic cells, Rho GTPases may be activated during apoptosis when they are released from the inhibitory actions of the D4 - GDI protein, a GDI for Rho family proteins, which is cleaved by caspase-3 (Figure 2 and Table 2). ${ }^{73-75}$ Since RhoA, Rac1 and Cdc42 all bind to D4-GDI in 


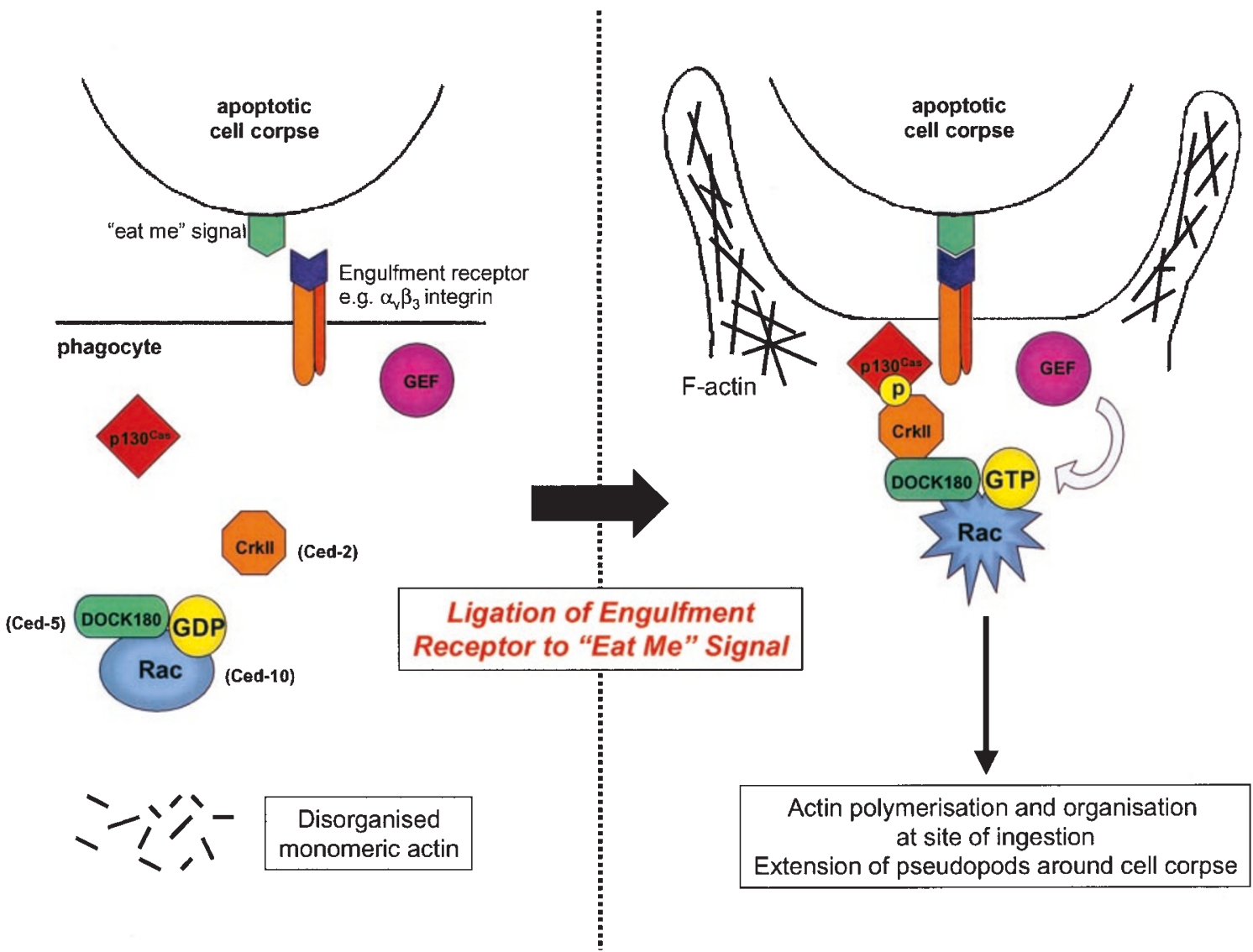

Figure 4 Mammalian homologues of the Ced-2, -5 , and -10 engulfment genes form a signalling cassette that drives actin polymerisation at the site of cell corpse ingestion. Left, Cell undergoing apoptosis displays 'eat me' signal on outer leaflet of plasma membrane. Minimal actin structures in the resting phagocye due to low levels of active Rac-GTP. Right, upon ligation of the 'eat me' signal to an engulfment receptor such as $\alpha_{v} \beta_{3}$ integrin expressed on the approaching phagocyte, a number of events occur that result in actin polymerisation. Integrin ligation results in tyrosine phosphorylation of the adaptor protein p130Cas, which subsequently recruits Crkll, and the Rac-GDP binding protein DOCK180, to the plasma membrane. Now proximal to its GEF, Rac exchanges GDP for GTP resulting in actin polymerisation at the ingestion site. The newly polymerised actin filaments form pseudopods that migrate around the cell corpse and eventually fuse to complete the process of engulfment. GEF, Guanine nucleotide Exchange Factor

vitro, it is not clear what the effect of D4-GDI cleavage and potential simultaneous activation of these multiple pathways during apoptosis would be.

Vav1 The haematopoietic-specific RhoGEF Vav1, which is essential for normal $\mathrm{T}$ and $\mathrm{B}$ cell function, ${ }^{78,79}$ was shown to be cleaved by caspase- 3 at a site that is also conserved in the related Vav2 and Vav3 proteins. ${ }^{80}$ The consequences of caspase-mediated cleavage of Vav1 are not clear, however, ectopic expression of $\mathrm{N}$-terminally deleted versions of Vav1 was sufficient to induce Rho-dependent actin stress fibres (MF Olson, unpublished observations and references ${ }^{81,82}$ ). Thus, it is possible that cleavage of Vav1 serves to disrupt signalling from the $T$ and $B$ cell receptors and to promote rearrangements of the actin cytoskeleton that lead to the morphological changes in apoptotic immune cells.

Given the large and complex pattern of protein degradation during apoptosis (see Tables 1 and 2), some apparently opposing activities would seem to be simultaneously in effect, for example the increased actin-myosin interactions and contractile force generation driven by cleaved ROCK I versus the actin-myosin disassembly and cell spreading from cleaved PAK2. These seemingly contradictory actions are likely influenced by differences in when and where a given protein is cleaved. In addition, signal intensity would determine which outcome predominates and the ultimate effects would change as relative signal strengths shifted over time. Many protein cleavage events probably do not contribute directly to the morphological changes or to the apoptotic process, rather these proteins are likely 'innocent bystanders' caught up in caspase-crossfire.

\section{Rho GTPases in phagocytosis}

For normal tissue homeostasis to be maintained in the presence of cells undergoing apoptosis, the associated cell debris must be efficiently removed and destroyed. Therefore, programmed cell death in vivo must occur hand-in-hand with corpse clearance; for this reason phagocytosis is essential as the final step of the apoptotic process. Removal of dying cells 
Table 2 Rho GTPase signalling proteins cleaved by caspases during apoptosis

\begin{tabular}{llcc}
\hline Protein & Function & Caspase & References \\
\hline ROCK I & Rho effector kinase & 3 & 23,24 \\
PRK1/PKN & Rho effector kinase & 3 & 54 \\
PRK2 & Rho effector kinase & 3 & 55 \\
Pak2/ $\gamma$-PAKI & Rac/Cdc42 effector kinase & 3 & $56,57,163$ \\
D4-GDI & Rho GDP dissociation & 3 & $73-75$ \\
& inhibitor & & \\
Rac1 & Rho family GTPase & 3,7 & 71 \\
Cdc42 & Rho family GTPase & 3,7 & 71 \\
Vav1 & Rho family GEF & 3 & 80 \\
\hline
\end{tabular}

prior to their lysis prevents the exposure of surrounding cells and tissue to potentially toxic cell contents, thus protecting from inflammatory injury. ${ }^{83,84}$ Phagocytosis of cell corpses occurs by both 'professional' phagocytes such as macrophages and neutrophils and 'amateur' phagocytes that include epithelial cells and fibroblasts.

\section{Actin cytoskeleton}

A universal requirement for the process of phagocytosis is the integrity of the actin cytoskeleton. The requirement for polymerised actin is highlighted by the inhibition of phagocytosis by actin disrupting agents such as cytochalasins. ${ }^{85-87}$ Bound particles are surrounded by a phagocytic cup lined by newly polymerised actin microfilaments that provide the driving force for engulfment and subsequent phagosome formation (Figure 1). ${ }^{88,89}$ Following internalisation of the particle, F-actin is depolymerised and dissociated from the phagosome allowing subsequent endosomal fusion and lysosomal degradation of the ingested particle..$^{90}$

\section{Labelling cell corpses and recognition by phagocytes}

Efficient clearance of apoptotic bodies also depends upon their being labelled with 'eat me' signals, which appears to be an integral part of the apoptotic process. ${ }^{91}$ The best characterised engulfment signal is the appearance of phosphatidylserine on the outer leaflet of the plasma membrane, an event that may be a key determinant in phagocyte recognition through its binding to an evolutionarily-conserved receptor. ${ }^{92}$ Less well characterised phagocytic markers include sites that bind 'bridging' molecules from the extracellular fluid such as $\beta_{2}$ glycoprotein $1,{ }^{93}$ thrombospondin $^{94}$ and the complement factors iC3b and C1q. ${ }^{95-97}$

Engulfment signals such as phosphatidylserine and bridging factors mediate phagocytosis through their interaction with specific receptors present on the approaching phagocyte. A variety of engulfment receptors involved in the clearance of dying cells have been identified including phagocyte lectins, integrins, scavenger receptors and macrosialin. ${ }^{89,98}$ Other factors may also influence the engulfment process, such as local changes in the lipid composition of the phagocyte plasma membrane. These changes in lipid composition are controlled in part by the $A B C 1$ transporter, ${ }^{99}$ which is required for efficient recognition of apoptotic cells. ${ }^{100}$

\section{Genetic analysis of phagocytosis in Caenorhabditis elegans}

$A B C 1$ is the mammalian homologue of the ced-7 gene from Caenorhabditis elegans, one of six genes identified in genetic screens for mutants defective in the clearance of apoptotic cells. ${ }^{101-103}$ These genes comprise two parallel pathways organised into the epistatic groups ced-2, ced-5, ced-10 and ced-1, ced-6, ced-7 (Table 3). ${ }^{102}$ Of the other components of the ced-7 pathway, ced-1 encodes a transmembrane receptor with homology to human SREC (Scavenger Receptor from Endothelial Cells) ${ }^{104}$ and ced-6 encodes a functionally conserved signalling adaptor molecule composed of a phosphotyrosine-binding domain and potential Src-homology domain 3 (SH3) binding sites. ${ }^{105,106}$ How the ced-1/6/7 pathway conveys signals downstream of activated engulfment receptors to the subsequent internalisation of the apoptotic cell is poorly understood. This is in contrast to our relatively thorough understanding of the ced-2/5/10 pathway, the components of which are not only required for cell corpse engulfment, but also for migration of the distal tip cells of the nematode gonad. ${ }^{107,108}$ This 'engulfment cassette' comprises a conserved signalling pathway previously implicated in regulation of the actin cytoskeleton and cell migration in mammalian cells.

\section{Mammalian homologues of ced engulfment genes}

Ced-2 encodes the homologue of the mammalian $\mathrm{SH} 2 /$ SH3-containing adaptor protein Crkll, ced-5 is homologous to the large adaptor protein DOCK180, whilst ced-10 is the nematode orthologue of Rac1 (Table 3). ${ }^{107,108}$ DOCK180 has been implicated in the activation of Rac since it has been shown to bind Rac-GDP, but not Cdc42 or RhoA, and overexpression of membrane-targeted DOCK180 increases Rac-GTP levels in 293T cells. ${ }^{109-111}$ Membrane targeting of DOCK180 induces spreading of NIH 3T3 cells $^{112}$ that is dependent on Rac function. ${ }^{109}$ Although DOCK180 can increase Rac-GTP levels, it contains no discernible Dbl-homology GEF domain and is therefore unlikely to act as a Rac GEF itself. ${ }^{109}$ Instead, DOCK180 may act as an adaptor that recruits Rac to the plasma membrane where it becomes activated (Figure 4). Although the Rac exchange factor(s) that mediates DOCK180dependent Rac activation is unknown, it has been shown that DOCK180 can enhance the activation of Rac by the GEF Vav1. ${ }^{109}$

Translocation of DOCK180/Rac to the plasma membrane is likely achieved through the interaction of DOCK180 with the amino terminal $\mathrm{SH} 3$ domain of the ced-2 homologue, Crkll. Crkll localises to focal adhesions upon integrin stimulation, a process that is dependent on its interaction with a protein called p130 Cas 113,114 Integrin stimulation results in tyrosine phosphorylation of 
Table 3 C. elegans genes involved in phagocytosis of cell corpses and their mammalian homologues

\begin{tabular}{|c|c|c|}
\hline Gene & Mammalian homologue & Possible function \\
\hline Ced-1 & SREC & Scavenger receptor; may recognise 'eat me' signal on cell corpse \\
\hline Ced-6 & hCED-6 & $\begin{array}{l}\text { Signalling adaptor protein; probably involved in relaying signal from } \\
\text { engulfment receptor to phagocytic machinery }\end{array}$ \\
\hline Ced-7 & $\mathrm{ABC} 1$ & Lipid transporter; modulates lipid composition of plasma membrane \\
\hline Ced-2 & Crkll & Signalling adaptor protein; binds DOCK180 and translocates to membrane \\
\hline Ced-5 & Dock180 & Adaptor protein; recruits Rac to Crkll and therefore plasma membrane for activation \\
\hline Ced-10 & Rac1 & Rho GTPase; promates actin polymerisation required for cell corpse internalisation \\
\hline
\end{tabular}

p130 Cas115-117 and subsequent recruitment of the Crkll/ DOCK180/Rac complex to focal adhesions ${ }^{109,110,118}$ via the Crkll SH2 domain (Figure 4). ${ }^{119,120}$ In addition, coexpression of $\mathrm{p} 130^{\mathrm{Cas}}$ and Crkll enhances the DOCK180dependent activation of Rac and membrane spreading. ${ }^{109,110}$ It would also be intriguing to determine whether the MER receptor tyrosine kinase, which has been suggested to be essential for the phagocytosis and clearance of apoptotic cells by macrophages, signals to the CrkII/DOCK180/Rac pathway. ${ }^{121}$

The mammalian homologues of the ced-2, -5 and -10 genes previously implicated in adhesion-dependent signalling and migration as described above, have recently been confirmed as important players in the clearance of apoptotic mammalian cells. ${ }^{122-124}$ Interestingly, it would appear that integrin-mediated formation of the CrkII/DOCK180 complex and subsequent Rac activation are common features of both cell adhesion and phagocyte signalling. Integrins such as $\alpha_{v} \beta_{5}$ and $\alpha_{v} \beta_{3}$ have previously been implicated as engulfment receptors in professional and amateur phagocytes. ${ }^{125-127}$ For example, phagocytosis of cell corpses by dendritic cells is mediated by the $\alpha_{v} \beta_{5}$ integrin, ${ }^{125}$ a process that was subsequently shown to depend on recruitment of the $\mathrm{p} 130^{\mathrm{Cas}} / \mathrm{CrkII} / \mathrm{DOCK} 180$ complex and subsequent Rac activation. $^{122}$

Other evidence exists that also implicates integrinmediated Rac activation in the phagocytosis of dying mammalian cells. The engulfment of apoptotic Baf-3 cells by bone marrow-derived macrophages was dependent on the $\alpha_{v} \beta_{3}$ integrin and could be blocked by dominant negative versions of $\mathrm{Rac}$ and $\mathrm{Cdc} 42 .{ }^{124}$ Interestingly, whereas inhibition of Rac or Cdc42 signalling significantly blocked phagocytic uptake, inhibition of Rho actually enhanced the clearance of cell corpses. ${ }^{124}$

There is growing evidence to suggest that members of the Rho GTPase family play a universal role in the reorganisation of the actin cytoskeleton during all forms of phagocytosis (reviewed in reference ${ }^{128}$ ). For instance, particles opsinised by IgG are recognised by the Fc $\gamma$ family of receptors for the constant region of immunoglobulin and are subsequently internalised in a Rac and Cdc42dependent manner. Inhibition of Rac function prevents pseudopod fusion and phagosome closure during FceRImediated phagocytosis, whilst inhibition of Cdc42 interferes with pseudopod extension. ${ }^{129-131}$ In contrast, internalisation of particles opsinised by complement fragments via binding to the $\alpha_{M} \beta_{2}$ integrin requires RhoA function, but not Rac and
Cdc42. ${ }^{130}$ During both Fc $\gamma$ - and $\alpha_{M} \beta_{2}$-mediated phagocytosis, the actin-nucleating Arp2/3 complex accumulates at the ingestion site to promote actin neo-polymerisation. ${ }^{132}$

\section{Are Rho GTPases required downstream of the ced-1/6/7 pathway?}

Considering the apparent general requirement for Rho GTPase signalling during phagocytosis it seems likely that they also play a role downstream of the ced-1/6/7 pathway. It is unlikely that ced-1 itself signals through ced-2/5 to ced-10 activation and actin-re-organisation however, since mutations to any of the ced-2, -5 , or -10 genes significantly co-operate with ced-1 mutations in the inhibition of engulfment. ${ }^{102}$ However, the possibility that components downstream of ced-1 interact with ced-10 was raised by the observation that overexpression of ced-6 could partially suppress the engulfment defect of ced-10 mutants. ${ }^{106}$ Since ced- 6 has been proposed to act as an adaptor molecule and does not possess an obvious catalytic domain, it is unclear whether it acts upstream or downstream of $c e d-10 .^{105,106,133,134}$ It is possible that the ced-1 pathway signals through an alternative Rac-like GTPase even in the presence of a ced-10 mutation since $C$. elegans express a Rac2 homologue ${ }^{135}$ and a GTPase termed Mig-2 that is $64 \%$ identical to ced-10. ${ }^{136}$ Interestingly, the scavenger receptor MARCO, which is involved in the macrophage clearance of bacteria, was recently shown to induce morphological changes associated with rearrangement of the actin cytoskeleton when overexpressed. ${ }^{137}$ These MARCO-induced changes were partially inhibited by dominant negative Rac, but not Cdc42. Perhaps a similar pathway exists downstream of other scavenger receptors or the $C$. elegans homologue ced-1 to regulate the actin cytoskeleton and phagocytosis of cell corpses via Rho GTPases.

Intriguing recent work suggests that besides their role in phagocytosis, the engulfment genes of $C$. elegans also may play an active role in the apoptotic process in the dying cell. A screen for genes that could synergise with a partial loss of function of the ced-3 caspase identified all the previously characterised engulfment genes. ${ }^{138,139} \mathrm{~A}$ model has been proposed whereby activation of engulfment pathways in the phagocyte promotes a feed forward mechanism that ensures the demise of the associated cell. Since Rho GTPases such as Rac are important effectors in engulfment signalling pathways, this raises the remarkable possibility that Rho proteins may be involved in the 
homicide of a cell previously thought to have committed suicide.

\section{Conclusions}

The actin cytoskeleton rearrangements in both the apoptotic and the phagocytic cell result from activation of signalling pathways associated with Rho GTPases. However, the mode of activation is entirely different in each case. During apoptosis, caspase-mediated cleavage of ROCK I gives rise to a constitutive Rho-independent signal that generates actinmyosin contractile force, membrane blebbing and formation of apoptotic bodies. In marked contrast, phagocytosis requires precise spatio-temporal regulation of Rac and Cdc42 to coordinate the dynamic actin remodelling necessary for the engulfment of the apoptotic cell.

It is evident that the actin rearrangements that accompany phagocytosis are critical for the removal of dying cells, thus preventing the exposure of surrounding cells and tissue to potentially toxic cell contents and an inappropriate immune response. However, it is not clear whether the membrane blebbing of an apoptotic cell plays an active part in its subsequent phagocytosis or if, in fact, it has any in vivo physiological purpose at all. Blebbing does appear to be essential for the formation of apoptotic bodies, which may facilitate recognition and clearance by phagocytes. Alternatively, the eventual breakdown of the cell into apoptotic bodies may aid the engulfment process. In addition, the contractile forces generated during the execution phase of apoptosis may be important for pulling adjacent cells with strong cellcell contacts together, thus maintaining proper tissue organisation and integrity. Having identified the biochemical pathway responsible for the cell contraction and membrane blebbing during apoptosis, it will now be possible to finally determine the physiological function of these processes and answer the question 'What is blebbing for?'

\section{Acknowledgements}

The authors were supported by The Royal Society and The Cancer Research Campaign at the Institute of Cancer Research. We thank Drs. D Croft, P Frankel, C Marshall, E Sahai and V Smits for critical reading of this manuscript.

\section{References}

1. Nicholson DW (1999) Caspase structure, proteolytic substrates, and function during apoptotic cell death. Cell Death Differ. 6: 1028-1042

2. Kerr JF, Wyllie AH and Currie AR (1972) Apoptosis: a basic biologica phenomenon with wide-ranging implications in tissue kinetics. Br. J. Cancer 26: 239-257

3. Mills JC, Stone NL and Pittman RN (1999) Extranuclear apoptosis. The role of the cytoplasm in the execution phase. J. Cell Biol. 146: 703-708

4. Takai Y, Sasaki T and Matozaki T (2001) Small GTP-binding proteins. Physiol. Rev. 81: 153-208
5. Hall A (1998) Rho GTPases and the actin cytoskeleton. Science 279: 509-514

6. Paterson HF, Self AJ, Garrett MD, Just I, Aktories K and Hall A (1990) Microinjection of recombinant $\mathrm{p} 21$ rho induces rapid changes in cell morphology. J. Cell Biol. 111: 1001-1007

7. Ridley AJ and Hall A (1992) The small GTP-binding protein rho regulates the assembly of focal adhesions and actin stress fibers in response to growth factors. Cell 70: 389-399

8. Ridley AJ, Paterson HF, Johnston CL, Diekmann D and Hall A (1992) The small GTP-binding protein rac regulates growth factor-induced membrane ruffling. Cell 70: 401-410

9. Kozma R, Ahmed S, Best A and Lim L (1995) The Ras-related protein Cdc42Hs and bradykinin promote formation of peripheral actin microspikes and filopodia in Swiss 3T3 fibroblasts. Mol. Cell Biol. 15: 1942-1952

10. Nobes CD and Hall A (1995) Rho, rac, and cdc42 GTPases regulate the assembly of multimolecular focal complexes associated with actin stress fibers, lamellipodia, and filopodia. Cell 81: 53-62

11. Cotter TG, Lennon SV, Glynn JM and Green DR (1992) Microfilamentdisrupting agents prevent the formation of apoptotic bodies in tumor cells undergoing apoptosis. Cancer Res. 52: 997-1005

12. Laster SM and Mackenzie Jr JM (1996) Bleb formation and F-actin distribution during mitosis and tumor necrosis factor-induced apoptosis. Microsc. Res. Tech. 34: $272-280$

13. Vemuri GS, Zhang J, Huang R, Keen JH and Rittenhouse SE (1996) Thrombin stimulates wortmannin-inhibitable phosphoinositide 3-kinase and membrane blebbing in CHRF-288 cells. Biochem. J. 314: 805-810

14. Pitzer F, Dantes A, Fuchs T, Baumeister W and Amsterdam A (1996) Removal of proteasomes from the nucleus and their accumulation in apoptotic blebs during programmed cell death. FEBS Lett. 394: 47-50

15. Mills JC, Stone NL, Erhardt J and Pittman RN (1998) Apoptotic membrane blebbing is regulated by myosin light chain phosphorylation. J. Cell Biol. 140: $627-636$

16. Torgerson RR and McNiven MA (1998) The actin-myosin cytoskeleton mediates reversible agonist-induced membrane blebbing. J. Cell Sci. 111: 2911-2922

17. Huot J, Houle F, Rousseau S, Deschesnes RG, Shah GM and Landry J (1998) SAPK2/p38-dependent F-actin reorganization regulates early membrane blebbing during stress-induced apoptosis. J. Cell Biol. 143: 1361-1373

18. RaoJY, Jin YS, Zheng Q, Cheng J, Tai J and Hemstreet III GP (1999) Alterations of the actin polymerization status as an apoptotic morphological effector in $\mathrm{HL}$ 60 cells. J. Cell Biochem. 75: 686-697

19. Hagmann J, Burger MM and Dagan D (1999) Regulation of plasma membrane blebbing by the cytoskeleton. J. Cell Biochem. 73: 488-499

20. Suarez-Huerta N, Mosselmans R, Dumont JE and Robaye B (2000) Actin depolymerization and polymerization are required during apoptosis in endothelial cells. J. Cell Physiol. 184: 239-245

21. Rentsch PS and Keller H (2000) Suction pressure can induce uncoupling of the plasma membrane from cortical actin. Eur. J. Cell. Biol. 79: 975-981

22. Petrache I, Verin AD, Crow MT, Birukova A, Liu F and Garcia JG (2001) Differential effect of MLC kinase in TNF-alpha-induced endothelial cell apoptosis and barrier dysfunction. Am. J. Physiol. Lung Cell. Mol. Physiol. 280: L1168-L1178

23. Coleman ML, Sahai EA, Yeo M, Bosch M, Dewar A and Olson MF (2001) Membrane blebbing during apoptosis results from caspase-mediated activation of ROCK I. Nat. Cell. Biol. 3: 339-345

24. Sebbagh M, Renvoize C, Hamelin J, Riche N, Bertoglio J and Breard J (2001) Caspase-3-mediated cleavage of ROCK I induces MLC phosphorylation and apoptotic membrane blebbing. Nat. Cell. Biol. 3: 346-352

25. Kayalar C, Ord T, Testa MP, Zhong LT and Bredesen DE (1996) Cleavage of actin by interleukin 1 beta-converting enzyme to reverse DNase I inhibition. Proc. Natl. Acad. Sci. USA 93: 2234-2238

26. Mashima T, Naito M, Noguchi K, Miller DK, Nicholson DW and Tsuruo T (1997) Actin cleavage by CPP-32/apopain during the development of apoptosis. Oncogene 14: 1007-1012

27. McCarthy NJ, Whyte MK, Gilbert CS and Evan GI (1997) Inhibition of Ced-3/ ICE-related proteases does not prevent cell death induced by oncogenes, DNA damage, or the Bcl-2 homologue Bak. J. Cell. Biol. 136: 215-227

28. Robertson D, Paterson HF, Adamson P, Hall A and Monaghan P (1995) Ultrastructural localization of ras-related proteins using epitope-tagged plasmids. J. Histochem. Cytochem. 43: 471-480 
29. Jin S, Shimizu M, Balasubramanyam A and Epstein HF (2000) Myotonic dystrophy protein kinase (DMPK) induces actin cytoskeletal reorganization and apoptotic-like blebbing in lens cells. Cell Motil Cytoskeleton 45: 133-148

30. Hirose M, Ishizaki T, Watanabe N, Uehata M, Kranenburg O, Moolenaar WH Matsumura F, Maekawa M, Bito H and Narumiya S (1998) Molecular dissection of the Rho-associated protein kinase (p160ROCK)-regulated neurite remodeling in neuroblastoma N1E-115 cells. J. Cell. Biol. 141: 1625-1636

31. Watanabe N, Kato T, Fujita A, Ishizaki T and Narumiya S (1999) Cooperation between $m$ Dia1 and ROCK in Rho-induced actin reorganization. Nat. Cell. Biol. 1: $136-143$

32. Tominaga T, Sahai E, Chardin P, McCormickF, Courtneidge SA and Alberts AS (2000) Diaphanous-related formins bridge Rho GTPase and Src tyrosine kinase signaling. Mol. Cell. 5: 13-25

33. Matsui T, Amano M, Yamamoto T, Chihara K, Nakafuku M, Ito M, Nakano T, Okawa K, Iwamatsu A and Kaibuchi K (1996) Rho-associated kinase, a novel serine/threonine kinase, as a putative target for small GTP binding protein Rho. EMBO J. 15: 2208-2216

34. Leung T, Chen XQ, Manser E and Lim L (1996) The p160 RhoA-binding kinase ROKalphais a member of a kinase family and is involved in the reorganization of the cytoskeleton. Mol. Cell. Biol. 16: 5313-5327

35. Ishizaki T, Maekawa M, Fujisawa K, Okawa K, Iwamatsu A, Fujita A, Watanabe N, Saito Y, Kakizuka A, Morii N and Narumiya S (1996) The small GTP-binding protein Rho binds to and activates a $160 \mathrm{kDa}$ Ser/Thr protein kinase homologous to myotonic dystrophy kinase. EMBO J. 15: 1885-1893

36. Ishizaki T, Naito M, Fujisawa K, Maekawa M, Watanabe $N$, Saito $Y$ and Narumiya S (1997) p160ROCK, a Rho-associated coiled-coil forming protein kinase, works downstream of Rho and induces focal adhesions. FEBS Lett. 404: $118-124$

37. Amano M, Chihara K, Kimura K, Fukata Y, Nakamura N, Matsuura $Y$ and Kaibuchi K (1997) Formation of actin stress fibers and focal adhesions enhanced by Rho-kinase. Science 275: 1308-1311

38. Amano M, Chihara K, Nakamura N, Kaneko T, Matsuura $Y$ and Kaibuchi $K$ (1999) The $\mathrm{COOH}$ terminus of Rho-kinase negatively regulates rho-kinase activity. J. Biol. Chem. 274: 32418-32424

39. Amano T, Tanabe K, Eto T, Narumiya S and Mizuno K (2001) LIM-kinase 2 induces formation of stress fibres, focal adhesions and membrane blebs, dependent on its activation by Rho-associated kinase-catalysed phosphorylation at threonine-505. Biochem. J. 354: 149-159

40. Sumi T, Matsumoto K and Nakamura T (2001) Specific activation of LIM kinase 2 via phosphorylation of threonine 505 by ROCK, a Rho-dependent protein kinase. J. Biol. Chem. 276: 670-676

41. Ohashi K, Nagata K, Maekawa M, Ishizaki T, Narumiya S and Mizuno K (2000) Rho-associated kinase ROCK activates LIM-kinase 1 by phosphorylation at threonine 508 within the activation loop. J. Biol. Chem. 275: 3577-3582

42. Maekawa M, Ishizaki T, Boku S, Watanabe N, Fujita A, Iwamatsu A, Obinata T, Ohashi K, Mizuno K and Narumiya S (1999) Signaling from Rho to the actin cytoskeleton through protein kinases ROCK and LIM-kinase. Science 285: 895-898

43. Amano M, Ito M, Kimura K, Fukata $Y$, Chihara K, Nakano T, Matsuura $Y$ and KaibuchiK(1996)Phosphorylation and activation of myosin by Rho-associated kinase (Rho-kinase). J. Biol. Chem. 271: 20246-20249

44. KureishiY, Kobayashi S, Amano M, Kimura K, Kanaide H, Nakano T, KaibuchiK and Ito M (1997) Rho-associated kinase directly induces smooth muscle contraction through myosin light chain phosphorylation. J. Biol. Chem. 272: 12257-12260

45. Totsukawa G, Yamakita Y, Yamashiro S, Hartshorne DJ, Sasaki Y and Matsumura F (2000) Distinct roles of ROCK (Rho-kinase) and MLCK in spatial regulation of MLC phosphorylation for assembly of stress fibers and focal adhesions in 3T3 fibroblasts. J. Cell Biol. 150: 797-806

46. Kimura K, Ito M, Amano M, Chihara K, Fukata Y, Nakafuku M, Yamamori B, Feng J, Nakano T, Okawa K, Iwamatsu A and Kaibuchi K (1996) Regulation of myosin phosphatase by Rho and Rho-associated kinase (Rho-kinase). Science 273: 245-248

47. Kawano Y, Fukata Y, Oshiro N, Amano M, Nakamura T, Ito M, Matsumura F, Inagaki M and Kaibuchi K (1999) Phosphorylation of myosin-binding subunit (MBS) of myosin phosphatase by Rho-kinase in vivo. J. Cell Biol. 147: 10231038

48. Kaneko T, Amano M, Maeda A, Goto H, Takahashi K, Ito M and Kaibuchi K (2000) Identification of calponin as a novel substrate of Rho-kinase. Biochem. Biophys. Res. Commun. 273: 110-116
49. Koyama M, Ito M, Feng J, Seko T, Shiraki K, Takase K, Hartshorne DJ and Nakano T (2000) Phosphorylation of CPI-17, an inhibitory phosphoprotein of smooth muscle myosin phosphatase, by Rho-kinase. FEBS Lett. 475: 197 200

50. Fedier A and Keller HU (1997) Suppression of bleb formation, locomotion, and polarity of Walker carcinosarcoma cells by hypertonic media correlates with cell volume reduction but not with changes in the F-actin content. Cell Motil. Cytoskeleton 37: 326-337

51. Dai J and Sheetz MP (1999) Membrane tether formation from blebbing cells. Biophys J. 77: 3363-3370

52. Rentsch PS and Keller H (2000) Suction pressure can induce uncoupling of the plasma membrane from cortical actin. Eur. J. Cell Biol. 79: 975-981

53. Cunningham CC, Gorlin JB, Kwiatkowski DJ, Hartwig JH, Janmey PA, Byers HR and Stossel TP (1992) Actin-binding protein requirement for cortical stability and efficient locomotion. Science 255: $325-327$

54. Takahashi M, Mukai H, Toshimori M, Miyamoto M and Ono Y (1998) Proteolytic activation of PKN by caspase-3 or related protease during apoptosis. Proc. Natl. Acad. Sci. USA 95: 11566-11571

55. Cryns VL, Byun Y, Rana A, MellorH, Lustig KD, Ghanem L, ParkerPJ, Kirschner MW and Yuan J (1997) Specific proteolysis of the kinase protein kinase Crelated kinase 2 by caspase- 3 during apoptosis. Identification by a novel, small pool expression cloning strategy. J. Biol. Chem. 272: 29449-29453

56. Rudel T and Bokoch GM (1997) Membrane and morphological changes in apoptotic cells regulated by caspase-mediated activation of PAK2. Science 276: $1572-1574$

57. Lee N, MacDonald H, Reinhard C, Halenbeck R, Roulston A, Shi T and Williams LT (1997) Activation of hPAK65 by caspase cleavage induces some of the morphological and biochemical changes of apoptosis. Proc. Natl. Acad. Sci. USA 94: $13642-13647$

58. Dong LQ, Landa LR, Wick MJ, Zhu L, Mukai H, Ono Y and Liu F (2000) Phosphorylation of protein kinase $\mathrm{N}$ by phosphoinositide-dependent protein kinase-1 mediates insulin signals to the actin cytoskeleton. Proc. Natl. Acad. Sci. USA 97: 5089-5094

59. Mukai H, Toshimori M, Shibata H, Takanaga $H$, Kitagawa M, Miyahara M, Shimakawa M and Ono Y (1997) Interaction of PKN with alpha-actinin. J. Biol. Chem. 272: $4740-4746$

60. Koh H, Lee KH, Kim D, Kim S, KimJW and Chung J(2000) Inhibition of Aktand its anti-apoptotic activities by tumor necrosis factor-induced protein kinase Crelated kinase 2 (PRK2) cleavage. J. Biol. Chem. 275: 34451-34458

61. Manser E, Huang HY, Loo TH, Chen XQ, Dong JM, Leung T and Lim L (1997) Expression of constitutively active alpha-PAK reveals effects of the kinase on actin and focal complexes. Mol. Cell Biol. 17: 1129-1143

62. Frost JA, Khokhlatchev A, Stippec S, White MA and Cobb MH (1998) Differential effects of PAK1-activating mutations reveal activity-dependent and -independent effects on cytoskeletal regulation. J. Biol. Chem. 273: 28191-28198

63. Zhao ZS, ManserE, Chen XQ, Chong C, Leung T and Lim L (1998) A conserved negative regulatory region in alphaPAK: inhibition of $P A K$ kinases reveals their morphological roles downstream of Cdc42 and Rac1. Mol. Cell Biol. 18: 21532163

64. van Leeuwen FN, van Delft S, Kain HE, van der Kammen RA and Collard JG (1999) Rac regulates phosphorylation of the myosin-II heavy chain, actinomyosin disassembly and cell spreading. Nat. Cell Biol. 1:242-248

65. Egelhoff TT, Lee RJ and Spudich JA (1993) Dictyostelium myosin heavy chain phosphorylation sites regulate myosin filament assembly and localization in vivo. Cell 75: $363-371$

66. Sanders LC, Matsumura F, Bokoch GM and de Lanerolle P (1999) Inhibition of myosin light chain kinase by p21-activated kinase. Science 283: 2083-2085

67. Goeckeler ZM, Masaracchia RA, Zeng Q, Chew TL, Gallagher P and Wysolmerski RB (2000) Phosphorylation of myosin light chain kinase by p21-activated kinase PAK2. J. Biol. Chem. 275: 18366-18374

68. Schurmann A, Mooney AF, Sanders LC, Sells MA, Wang HG, Reed JC and Bokoch GM (2000) p21-activated kinase 1 phosphorylates the death agonist bad and protects cells from apoptosis. Mol. Cell Biol. 20: 453-461

69. Tang Y, Zhou H, Chen A, Pittman RN and Field J (2000) The Aktproto-oncogene links Ras to Pak and cell survival signals. J. Biol. Chem. 275: 9106-9109

70. Jakobi R, Moertl E and Koeppel MA (2001) p21-activated protein kinase gamma-PAK suppresses programmed cell death of BALB3T3 fibroblasts. J. Biol. Chem. 276: 16624-16634 
71. Tu S and Cerione RA (2001) Cdc42 is a substrate for caspases and influences fas-induced apoptosis. J. Biol. Chem. 276: 19656-19663

72. Perona R, Montaner S, Saniger L, Sanchez-Perez I, Bravo R and Lacal JC (1997) Activation of the nuclear factor-kappaB by Rho, CDC42, and Rac-1 proteins. Genes Dev. 11: 463-475

73. Na S, Chuang TH, Cunningham A, Turi TG, Hanke JH, Bokoch GM and Danley DE (1996) D4-GDI, a substrate of CPP32, is proteolyzed during Fas-induced apoptosis. J. Biol. Chem. 271: 11209-11213

74. Danley DE, Chuang TH and Bokoch GM (1996) Defective Rho GTPase regulation by IL-1 beta-converting enzyme-mediated cleavage of D4 GDP dissociation inhibitor. J. Immunol. 157: 500-503

75. Krieser RJ and Eastman A (1999) Cleavage and nuclear translocation of the caspase 3 substrate Rho GDP-dissociation inhibitor, D4-GDI, during apoptosis. Cell Death Differ. 6: 412-419

76. Scherle P, Behrens T and Staudt LM (1993) Ly-GDI, a GDP-dissociation inhibitor of the RhoA GTP-binding protein, is expressed preferentially in lymphocytes. Proc. Natl. Acad. Sci. USA 90: 7568-7572

77. Adra CN, Ko J, Leonard D, Wirth LJ, Cerione RA and Lim B (1993) Identification of a novel protein with GDP dissociation inhibitor activity for the ras-like proteins CDC42Hs and rac I. Genes Chromosomes Cancer 8: 253-261

78. Zhang R, AltFW, Davidson L, Orkin SH and Swat W (1995) Defective signalling through the $\mathrm{T}$ - and B-cell antigen receptors in lymphoid cells lacking the vav proto-oncogene. Nature 374: $470-473$

79. Tarakhovsky A, Turner M, Schaal S, Mee PJ, Duddy LP, Rajewsky K and Tybulewicz VL (1995) Defective antigen receptor-mediated proliferation of $B$ and $T$ cells in the absence of Vav. Nature 374: 467-470

80. Hofmann TG, Hehner SP, Droge W and Schmitz ML (2000) Caspasedependent cleavage and inactivation of the Vav1 proto-oncogene product during apoptosis prevents IL-2 transcription. Oncogene 19: 1153-1163

81. Kranewitter WJ and Gimona M (1999) N-terminally truncated Vav induces the formation of depolymerization-resistant actin filaments in NIH 3 T3 cells. FEBS Lett. 455: 123-129

82. Olson MF, Pasteris NG, Gorski JL and Hall A (1996) Faciogenital dysplasia protein (FGD1) and Vav, two related proteins required for normal embryonic development, are upstream regulators of Rho GTPases. Curr. Biol. 6: 16281633

83. Ren Y and Savill J (1998) Apoptosis: the importance of being eaten. Cell Death Differ. 5: 563-568

84. Savill J (1997) Recognition and phagocytosis of cells undergoing apoptosis. Br. Med. Bull. 53: 491-508

85. Castellano F, Montcourrier $P$ and Chavrier $P(2000)$ Membrane recruitment of Rac1 triggers phagocytosis. J. Cell Sci. 113: 2955-2961

86. Greenberg S, el Khoury J, di Virgilio F, Kaplan EM and Silberstein SC (1991) $\mathrm{Ca}(2+)$-independent F-actin assembly and disassembly during $\mathrm{Fc}$ receptormediated phagocytosis in mouse macrophages. J. Cell Biol. 113: 757-767

87. Zigmond SH and Hirsch JG (1972) Effects of cytochalasin B on polymorphonuclear leucocyte locomotion, phagocytosis and glycolysis. Exp. Cell. Res. 73: 383-393

88. Allen LA and Aderem A (1996) Molecular definition of distinct cytoskeletal structures involved in complement- and Fc receptor-mediated phagocytosis in macrophages. J. Exp. Med. 184:627-637

89. Kwiatkowska K and Sobota A (1999) Signaling pathways in phagocytosis. Bioessays 21: 422-431

90. Bengtsson T, Jaconi ME, Gustafson M, Magnusson KE, Theler JM, Lew DP and Stendahl O (1993) Actin dynamics in human neutrophils during adhesion and phagocytosis is controlled by changes in intracellular free calcium. Eur. J. Cell. Biol. 62: 49-58

91. Savill Jand Fadok V (2000) Corpse clearance defines the meaning of cell death. Nature 407: 784-788

92. Fadok VA, Bratton DL, Rose DM, Pearson A, Ezekewitz RA and Henson PM (2000) A receptor for phosphatidylserine-specific clearance of apoptotic cells. Nature 405: 85-90

93. Balasubramanian K, Chandra J and Schroit AJ (1997) Immune clearance of phosphatidylserine-expressing cells by phagocytes. The role of beta2glycoprotein I in macrophage recognition. J. Biol. Chem. 272: 31113-31117

94. Savill J, Hogg N, Ren Y and Haslett C (1992) Thrombospondin cooperates with CD36 and the vitronectin receptor in macrophage recognition of neutrophils undergoing apoptosis. J. Clin. Invest. 90: 1513-1522
95. Mevorach D, Mascarenhas JO, Gershov D and Elkon KB (1998) Complementdependent clearance of apoptotic cells by human macrophages. J. Exp. Med. 188: $2313-2320$

96. Botto M, Dell'Agnola C, Bygrave AE, Thompson EM, Cook HT, Petry F, Loos M, Pandolfi PP and Walport MJ (1998) Homozygous C1q deficiency causes glomerulonephritis associated with multiple apoptotic bodies. Nat. Genet. 19: $56-59$

97. Taylor PR, Carugati A, Fadok VA, Cook HT, Andrews M, Carroll MC, Savill JS, Henson PM (2000) A hierarchical role for classical pathway complement proteins in the clearance of apoptotic cells in vivo. J. Exp. Med. 192: 359-366

98. Platt N, da Silva RP and Gordon S (1998) Recognizing death: the phagocytosis of apoptotic cells. Trends Cell Biol. 8: 365-372

99. Marguet D, Luciani MF, Moynault A, Williamson P and Chimini G (1999) Engulfment of apoptotic cells involves the redistribution of membrane phosphatidylserine on phagocyte and prey. Nat. Cell Biol. 1:454-456

100. Hamon Y, Broccardo C, Chambenoit O, Luciani MF, Toti F, Chaslin S, Freyssinet JM, Devaux PF, McNeish J, Marguet D and Chimini G (2000) ABC1 promotes engulfment of apoptotic cells and transbilayer redistribution of phosphatidylserine. Nat. Cell. Biol. 2: 399-406

101. Hedgecock EM, Sulston JE and Thomson JN (1983) Mutations affecting programmed cell deaths in the nematode Caenorhabditis elegans. Science 220: $1277-1279$

102. Ellis RE, Jacobson DM and Horvitz HR (1991) Genes required for the engulfment of cell corpses during programmed cell death in Caenorhabditis elegans. Genetics 129: 79-94

103. Chung S, Gumienny TL, Hengartner MO and Driscoll M (2000) A common set of engulfment genes mediates removal of both apoptotic and necrotic cell corpses in C. elegans. Nat. Cell. Biol. 2: 931-937

104. Zhou Z, Hartwieg E and Horvitz HR (2001) CED-1 is a transmembrane receptor that mediates cell corpse engulfment in C. elegans. Cell 104: 43-56

105. Su HP, Brugnera E, Van Criekinge W, Smits E, Hengartner M, Bogaert T and Ravichandran KS (2000) Identification and characterization of a dimerization domain in CED-6, an adapter protein involved in engulfment of apoptotic cells. J. Biol. Chem. 275: 9542-9549

106. Liu QA and Hengartner MO (1998) Candidate adaptor protein CED-6 promotes the engulfment of apoptotic cells in C. elegans. Cell 93: 961-972

107. Reddien PW and Horvitz HR (2000) CED-2/Crkll and CED-10/Rac control phagocytosis and cell migration in Caenorhabditis elegans. Nat. Cell Biol. 2: $131-136$

108. Wu YC and Horvitz HR (1998) C. elegans phagocytosis and cell-migration protein CED-5 is similar to human DOCK180. Nature 392: 502-504

109. Kiyokawa E, Hashimoto $Y$, Kobayashi S, Sugimura H, Kurata T and Matsuda $M$ (1998) Activation of Rac1 by a Crk SH3-binding protein, DOCK180. Genes Dev. 12: $3331-3336$

110. Kiyokawa E, Hashimoto $Y$, Kurata T, Sugimura $H$ and Matsuda M (1998) Evidence that DOCK180 up-regulates signals from the Crkll-p130(Cas) complex. J. Biol. Chem. 273: 24479-24484

111. Nolan KM, Barrett K, Lu Y, Hu KQ, Vincent S and Settleman J (1998) Myoblast city, the Drosophila homolog of DOCK180/CED-5, is required in a Rac signaling pathway utilized for multiple developmental processes. Genes Dev. 12:33373342

112. Hasegawa H, Kiyokawa E, Tanaka S, Nagashima K, Gotoh N, Shibuya M, Kurata T and Matsuda M (1996) DOCK180, a major CRK-binding protein, alters cell morphology upon translocation to the cell membrane. Mol. Cell Biol. 16: $1770-1776$

113. Vuori K, Hirai H, Aizawa S and Ruoslahti E (1996) Introduction of p130cas signaling complex formation upon integrin-mediated cell adhesion: a role for Src family kinases. Mol. Cell Biol. 16: 2606-2613

114. Nievers MG, Birge RB, Greulich H, Verkleij AJ, Hanafusa $H$ and van Bergen en Henegouwen PM (1997) v-Crk-induced cell transformation: changes in focal adhesion composition and signaling. J. Cell Sci. 110: 389-399

115. Nojima $Y$, Morino N, Nimura $T$, Hamasaki K, Furuya $H$, Sakai $R$, Sato $T$, Tachibana K, Morimoto $C$ and Yazaki Y et al (1995) Integrin-mediated cell adhesion promotes tyrosine phosphorylation of p130Cas, a Src homology 3containing molecule having multiple Src homology 2-binding motifs. J. Biol. Chem. 270: 15398-15402 
116. Vuori K and Ruoslahti E (1995) Tyrosine phosphorylation of p130Cas and cortactin accompanies integrin-mediated cell adhesion to extracellular matrix. J. Biol. Chem. 270: 22259-22262

117. Nakamoto T, Sakai R, Honda H, Ogawa S, Ueno H, Suzuki T, Aizawa S, Yazaki $\mathrm{Y}$ and Hirai $\mathrm{H}$ (1997) Requirements for localization of p130cas to focal adhesions. Mol. Cell Biol. 17: 3884-3897

118. Gu J, Sumida Y, Sanzen N and Sekiguchi K (2001) Laminin-10/11 and fibronectin differentially regulate integrin-dependent $R$ ho and rac activation via p130Cas-Crkll-DOCK180 pathway. J. Biol. Chem. 21: 21

119. Feller SM, Ren R, Hanafusa Hand Baltimore D (1994) SH2 and SH3 domains as molecular adhesives: the interactions of $\mathrm{Crk}$ and $\mathrm{Abl}$. Trends Biochem. Sci. 19: 453-458

120. Matsuda M, Nagata S, Tanaka S, Nagashima K and Kurata T (1993) Structural requirement of CRK SH2 region for binding to phosphotyrosine-containing proteins. Evidence from reactivity to monoclonal antibodies. J. Biol. Chem. 268: $4441-4446$

121. Scott RS, McMahon EJ, Pop SM, Reap EA, Caricchio R, Cohen PL, Earp HS and Matsushima GK (2001) Phagocytosis and clearance of apoptotic cells is mediated by MER. Nature 411: 207-211

122. Albert ML, Kim Jl and Birge RB (2000) Alphavbeta5 integrin recruits the CrkllDock180-rac1 complex for phagocytosis of apoptotic cells. Nat. Cell Biol. 2: 899-905

123. Tosello-Trampont AC, Brugnera E and Ravichandran KS (2001) Evidence for a conserved role for CRKII and Rac in engulfment of apoptotic cells. J. Biol. Chem. 276: 13797-13802

124. Leverrier $Y$ and Ridley AJ (2001) Requirement for Rho GTPases and PI3kinases during apoptotic cell phagocytosis by macrophages. Curr. Biol. 11: 195-199

125. Albert ML, Sauter B and Bhardwaj N (1998) Dendritic cells acquire antigen from apoptotic cells and induce class I-restricted CTLs. Nature 392: 86-89

126. Finnemann SC and Rodriguez-Boulan E (1999) Macrophage and retinal pigment epithelium phagocytosis: apoptotic cells and photoreceptors compete for alphavbeta3 and alphavbeta5 integrins, and protein kinase $C$ regulates alphavbeta 5 binding and cytoskeletal linkage. J. Exp. Med. 190: 861-874

127. Savill J, Dransfield I, Hogg N and Haslett C (1990) Vitronectin receptormediated phagocytosis of cells undergoing apoptosis. Nature 343: 170-173

128. Chimini $G$ and Chavrier $P$ (2000) Function of Rho family proteins in actin dynamics during phagocytosis and engulfment. Nat. Cell Biol. 2: E191-E196

129. Cox D, Chang P, Zhang Q, Reddy PG, Bokoch GM and Greenberg S (1997) Requirements for both Rac1 and Cdc42 in membrane ruffling and phagocytosis in leukocytes. J. Exp. Med. 186: 1487-1494

130. Caron E and Hall A (1998) Identification of two distinct mechanisms of phagocytosis controlled by different Rho GTPases. Science 282: 1717-1721

131. Massol P, Montcourrier $P$, Guillemot JC and Chavrier $P$ (1998) Fc receptormediated phagocytosis requires CDC42 and Rac1. EMBO J. 17: 6219-6229

132. May RC, Caron E, Hall A and Machesky LM (2000) Involvement of the Arp2/3 complex in phagocytosis mediated by FcgammaR or CR3. Nat. Cell Biol. 2 $246-248$

133. Liu QA and Hengartner MO (1999) Human CED-6 encodes a functional homologue of the Caernorhabditis elegans engulfment protein CED-6. Curr. Biol. 9: $1347-1350$

134. Smits E, Van Criekinge W, Plaetinck $G$ and Bogaert $T$ (1999) The human homologue of Caenorhabditis elegans CED-6 specifically promotes phagocytosis of apoptotic cells. Curr. Biol. 9: 1351-1354

135. Chen W, Yap SF and Lim L (1996) Isolation of the gene coding for Caenorhabditis elegans Rac2 homologue, a Ras-related small GTP-binding protein. Gene 180: 217-219

136. Zipkin ID, Kindt RM and Kenyon CJ (1997) Role of a new Rho family member in cell migration and axon guidance in C. elegans. Cell 90: 883-894

137. Pikkarainen T, Brannstrom A and Tryggvason K (1999) Expression of macrophage MARCO receptor induces formation of dendritic plasma membrane processes. J. Biol. Chem. 274: 10975-10982

138. Hoeppner DJ, Hengartner MO and Schnabel R (2001) Engulfment genes cooperate with ced-3 to promote cell death in Caenorhabditis elegans. Nature 412: $202-206$

139. Reddien PW, Cameron S and Horvitz HR (2001) Phagocytosis promotes programmed cell death in C. elegans. Nature 412: 198-202
140. Kothakota S, Azuma T, Reinhard C, Klippel A, Tang J, Chu K, McGarry TJ, Kirschner MW, Koths K, Kwiatkowski DJ and Williams LT (1997) Caspase-3generated fragment of gelsolin: effector of morphological change in apoptosis. Science 278: 294-298

141. Sgorbissa A, Benetti R, Marzinotto S, Schneider C and Brancolini C (1999) Caspase- 3 and caspase- 7 but not caspase- 6 cleave Gas2 in vitro: implications for microfilament reorganization during apoptosis. J. Cell Sci. 112: 4475-4482

142. Martin SJ, O'Brien GA, Nishioka WK, McGahon AJ, Mahboubi A, Saido TC and Green DR (1995) Proteolysis of fodrin (non-erythroid spectrin) during apoptotis. J. Biol. Chem. 270: 6425-6428

143. Slee EA, Adrain C and Martin SJ (2001) Executioner caspase-3, -6, and -7 perform distinct, non-redundant roles during the demolition phase of apoptosis. J. Biol. Chem. 276: 7320-7326

144. Wang KK, Posmantur R, Nath R, McGinnis K, Whitton M, Talanian RV, Glantz SB and Morrow JS (1998) Simultaneous degradation of alphall- and betallspectrin by caspase 3 (CPP32) in apoptotic cells. J. Biol. Chem. 273: 2249022497

145. Browne KA, Johnstone RW, Jans DA and Trapani JA (2000) Filamin (280-kDa actin-binding protein) is a caspase substrate and is also cleaved directly by the cytotoxic T lymphocyte protease granzyme B during apoptosis. J. Biol. Chem. 275: $39262-39266$

146. van de Water B, Tijdens IB, Verbrugge A, Huigsloot M, Dihal AA, Stevens JL, Jaken S and Mulder GJ (2000) Cleavage of the actin-capping protein alphaadducin at Asp-Asp-Ser-Asp633-Ala by caspase-3 is preceded by its phosphorylation on serine 726 in cisplatin-induced apoptosis of renal epithelial cells. J. Biol. Chem. 275: 25805-25813

147. Gervais FG, Thornberry NA, Ruffolo SC, Nicholson DW and Roy S (1998) Caspases cleave focal adhesion kinase during apoptosis to generate a FRNKlike polypeptide. J. Biol. Chem. 273: 17102-17108

148. Levkau B, Herren B, Koyama H, Ross R and Raines EW (1998) Caspasemediated cleavage of focal adhesion kinase pp125FAK and disassembly of focal adhesions in human endothelial cell apoptosis. J. Exp. Med. 187: 579586

149. Kook S, Shim SR, Choi SJ, Ahnn J, Kim JI, Eom SH, Jung YK, Paik SG and Song WK (2000) Caspase-mediated cleavage of p130cas in etoposide-induced apoptotic Rat-1 cells. Mol. Biol. Cell. 11: 929-939

150. Stegh AH, Herrmann H, Lampel S, Weisenberger D, Andra K, Seper M, Wiche G, Krammer PH and Peter ME (2000) Identification of the cytolinker plectin as a major early in vivo substrate for caspase 8 during CD95- and tumor necrosis factor receptor-mediated apoptosis. Mol. Cell Biol. 20: 5665-5679

151. SchmeiserKand Grand RJ (1999) The fate of E-and P-cadherin during the early stages of apoptosis. Cell Death Differ. 6: 377-386

152. Steinhusen U, Weiske J, Badcock V, Tauber R, Bommert Kand Huber O (2001) Cleavage and shedding of E-cadherin after induction of apoptosis. J. Biol. Chem. 276: 4972-4980

153. Hunter I, McGregor D and Robins SP (2001) Caspase-dependent cleavage of cadherins and catenins during osteoblast apoptosis. J. Bone Miner Res. 16: $466-477$

154. Brancolini C, Lazarevic D, Rodriguez J and Schneider C (1997) Dismantling cell-cell contacts during apoptosis is coupled to a caspase-dependent proteolytic cleavage of beta-catenin. J. Cell Biol. 139: 759-771

155. Brancolini C, Sgorbissa A and Schneider C (1998) Proteolytic processing of the adherens junctions components beta-catenin and gamma-catenin/plakoblobin during apoptosis. Cell Death Differ. 5: 1042-1050

156. Ku NO and Omary MB (2001) Effect of mutation and phosphorylation of type keratins on their caspase-mediated degradation. J. Biol. Chem. 16: 16

157. Badock V, Steinhusen U, Bommert K, Wittmann-Liebold B and Otto A (2001) Apoptosis-induced cleavage of keratin 15 and keratin 17 in a human breast epithelial cell line. Cell Death Differ. 8: 308-315

158. Caulin C, Salvesen GS and Oshima RG (1997) Caspase cleavage of keratin 18 and reorganization of intermediate filaments during epithelial cell apoptosis. J. Cell Biol. 138: 1379-1394

159. Prasad S, Soldatenkov VA, Srinivasarao G and Dritschilo A (1998) Identification of keratins 18,19 and heat-chock protein 90 beta as candidate substrates of proteolysis during ionization radiation-induced apoptosis of estrogen-receptor negative breast tumor cells. Int. J. Oncol. 13: 757-764 
160. Prasad SC, Thraves PJ, Kuettel MR, Srinivasarao GY, Dritschilo A and Soldatenkov VA (1998) Apoptosis-associated proteolysis of vimentin in human prostate epithelial tumor cells. Biochem. Biophys. Res. Commun. 249: 332 338

161. Canu N, Dus L, Barbato C, Ciotti MT, Brancolini C, Rinaldi AM, Novak M, Cattaneo A, Bradbury A and Calissano P (1998) Tau cleavage and dephosphorylation in cerebellar granule neurons undergoing apoptosis. J. Neurosci. 18: 7061-7074

162. Fasulo L, Ugolini G, Visintin M, Bradbury A, Brancolini C, Verzillo V, Novak M and Cattaneo A (2000) The neuronal microtubule-associated protein tau is a substrate for caspase-3 and an effector of apoptosis. J. Neurochem. 75: 624633

163. Walter BN, Huang Z, Jakobi R, Tuazon PT, Alnemri ES, Litwack G and Traugh JA (1998) Cleavage and activation of $\mathrm{p} 21$-activated protein kinase gammaPAK by CPP32 (caspase 3). Effects of autophosphorylation on activity. J. Biol. Chem. 273: 28733-28739 